\title{
Biochemical Characterization of Mycoplasma agalactiae subsp. agalactiae (Wroblewski) Freundt
}

\author{
JAWAD M. AL-AUBAIDI and A. H. DARDIRI
}

\author{
Plum Island Animal Disease Center, Agricultural Research Service, Greenport, New York 11944
}

\begin{abstract}
Sixty-two cultures representing 59 Mycoplasma strains from goats and sheep were purified, biochemically characterized, and serologically identified. All of the strains were identified as belonging to Mycoplasma agalactiae subsp. agalactiae (Wroblewski) Freundt by the metabolic-inhibition test. The serological reactions of the strains were specific and reproducible, and their biochemical characteristics were identical. The antigenic relationships among the strains investigated, other caprine and ovine mycoplasmas, and M. mycoides subsp. mycoides are discussed.
\end{abstract}

Mycoplasma agalactiae (Wroblewski) Freundt, the causal organism of contagious agalactia of sheep and goats initially isolated by Bridré and Donatien (5), was the first caprine and ovine Mycoplasma species established (8).

At present, contagious agalactia occurs in most of the Mediterranean countries, in Portugal, Switzerland, Rumania, Yugoslavia, Sudan, Iran, Pakistan, India, and the U.S.S.R. Detailed descriptions of the disease have been reported previously $(6,12,14-16)$.

The purpose of this study was to characterize biochemically and to identify serologically the large collection of caprine and ovine Mycoplasma strains accumulated at the Plum Island Animal Disease Center and to investigate their antigenic relationships to $M$. agalactiae, $M$. mycoides subsp. capri, $M$. mycoides subsp. mycoides, $M$. arginini, and nine distinct goat and sheep Mycoplasma strains.

Fifty-nine Mycoplasma strains, including strain PG 2, recently designated (9) as the neotype strain of $M$. agalactiae subsp.agalactiae, isolated from sheep and goats in various foreign countries were investigated (Table 1). In a few instances, cultures of the same strain were received from different laboratories, and all were included in the study. Some of the strains were previously identified as $M$. agalactiae by various investigators; the others were received as field isolates without having been characterized or identified. The strains used in the production of antisera are cited below.

The preparation of the culture media and the procedures used for culture purification, biochemical characterization, serological tests, and propagation of the organisms were described previously (1-3).
Biochemical characterization of the strains included carbohydrate fermentation, reduction of tetrazolium chloride and methylene blue, deamination of arginine hydrochloride, urease activity, formation of "film and spots," and hemolysis of sheep red blood cells. Other tests were: growth in medium containing $0.02 \%$ methylene blue, growth in serum-free medium, growth in bile salt medium, and growth at $25 \mathrm{C}$.

Hyperimmune sera were prepared as described previously (10) in rabbits against $M$. agalactiae subsp. agalactiae strain PG2 and $M$. mycoides subsp. mycoides strain G 230. Other strains (Mycoplasma and Acholeplasma) used for the production of antisera were Y-goat, A 1343 , KS-1, goat 145 , goat $189,19-\mathrm{L}, 14-\mathrm{Z}$, 2-D, and Y-98.

Serological Procedures. The metabolic-inhibition test (13), with tetrazolium chloride as a substrate indicator (2), was performed on all of the Mycoplasma strains.

The 59 strains studied were identified as $M$. agalactiae subsp. agalactiae. They reduced tetrazolium chloride and lysed sheep red blood cells, and all but four formed "film and spots"; they did not ferment carbohydrates, metabolize arginine hydrochloride, utilize urea, or grow at $25 \mathrm{C}$, but they did require serum for growth.

All of the strains were metabolically inhibited by specific antiserum prepared against the neotype strain (PG2) of $M$. agalactiae subsp. agalactiae at serum titers ranging between $1: 1,280$ and $1: 20,480$. The serological reactions were found to be specific and reproducible. In addition, the strains were typed with antisera representing 11 antigenically distinct caprine and ovine Mycoplasma serotypes. They were also compared with $M$. mycoides subsp. 
TABLE 1. Sources of the strains of Mycoplasma agalactiae subsp. agalactiae studied

\begin{tabular}{|c|c|c|c|c|c|}
\hline $\begin{array}{c}\text { Strain } \\
\text { designation }\end{array}$ & $\begin{array}{l}\text { Animal } \\
\text { origin }\end{array}$ & Supplied by & $\begin{array}{c}\text { Strain } \\
\text { designation }\end{array}$ & $\begin{array}{l}\text { Animal } \\
\text { origin }\end{array}$ & Supplied by \\
\hline PG 2 & Sheep & $\begin{array}{l}\text { E. A. Freundt, } \\
\text { Denmark }\end{array}$ & $\begin{array}{l}\text { Kirminshah (20) } \\
\text { Mashad (21) }\end{array}$ & $\begin{array}{l}\text { Sheep milk } \\
\text { Sheep milk }\end{array}$ & $\begin{array}{l}\text { M. Kaveh, Iran } \\
\text { M. Kaveh, Iran }\end{array}$ \\
\hline PG 2 & Sheep & $\begin{array}{l}\text { P. Perreau, } \\
\text { France }\end{array}$ & $\begin{array}{l}\text { Shiraz (23) } \\
\text { Shiraz V (26) }\end{array}$ & $\begin{array}{l}\text { Sheep milk } \\
\text { Sheep milk }\end{array}$ & $\begin{array}{l}\text { M. Kaveh, Iran } \\
\text { M. Kaveh, Iran }\end{array}$ \\
\hline PG 2 & Sheep & $\begin{array}{l}\text { D. G. ff. Edward, } \\
\text { England }\end{array}$ & $\begin{array}{l}\text { Shiraz (30) } \\
\text { Shiraz (32) }\end{array}$ & $\begin{array}{l}\text { Sheep milk } \\
\text { Sheep milk }\end{array}$ & $\begin{array}{l}\text { M. Kaveh, Iran } \\
\text { M. Kaveh, Iran }\end{array}$ \\
\hline $125 / 9 \mathrm{M}(2707)$ & Sheep ${ }^{a}$ & A. Foggie, Turkey & Karaj P 6 (33) & Sheep milk & M. Kaveh, Iran \\
\hline $125 / 9 \mathrm{M}(2219)$ & Sheep $a$ & A. Foggie, Turkey & Shiraz (35) & Sheep milk & M. Kaveh, Iran \\
\hline BSV (1709) & Sheep ${ }^{a}$ & A. Foggie, Turkey & Talghan (36) & Sheep milk & M. Kaveh, Iran \\
\hline AXZ (1391) & Sheep $a$ & A. Foggie, Turkey & Shiraz 1 (37) & Sheep milk & M. Kaveh, Iran \\
\hline AFH (557) & Sheep ${ }^{a}$ & A. Foggie, Turkey & Chatat (38) & Sheep milk & M. Kaveh, Iran \\
\hline 99M AIK (2511) & Sheep $^{a}$ & A. Foggie, Turkey & Shiraz Natami (39) & Sheep milk & M. Kaveh, Iran \\
\hline 99M AIK (2542) & Sheep ${ }^{a}$ & A. Foggie, Turkey & Shiraz (40) & Sheep milk & M. Kaveh, Iran \\
\hline ASU (1706) & Sheep ${ }^{a}$ & A. Foggie, Turkey & Chah Zebar (41) & Sheep milk & M. Kaveh, Iran \\
\hline $50 / 7 \mathrm{E}(657)$ & Sheep ${ }^{a}$ & A. Foggie, Turkey & Shiraz 1 (42) & Sheep milk & M. Kaveh, Iran \\
\hline BEH (484) & Sheep $a$ & A. Foggie, Turkey & Shiraz Sadegi (43) & Sheep milk & M. Kaveh, Iran \\
\hline BSV (440) & Sheep ${ }^{a}$ & A. Foggie, Turkey & Kerminshah (44) & Sheep milk & M. Kaveh, Iran \\
\hline $\cos 4(1063)$ & Sheep ${ }^{a}$ & A. Foggie, Turkey & Aligodar (45) & Sheep milk & M. Kaveh, Iran \\
\hline BFI & Sheep $a$ & A. Foggie, Turkey & Karaj 11 (46) & Sheep milk & M. Kaveh, Iran \\
\hline AFH & Sheep ${ }^{a}$ & A. Foggie, Turkey & Baraghan (47) & Sheep milk & M. Kaveh, Iran \\
\hline 99 Turkey & Sheep ${ }^{a}$ & A. Foggie, Turkey & Karaj (48) & Sheep milk & M. Kaveh, Iran \\
\hline H Goat & Goat $a$ & A. Foggie, Turkey & Lorestan (49) & Sheep milk & M. Kaveh, Iran \\
\hline H Goat & Goat $a$ & $\begin{array}{l}\text { G. S. Cottew, } \\
\text { Australia }\end{array}$ & $\begin{array}{l}\text { Egherbolagh (50) } \\
\text { Shiraz (53) }\end{array}$ & $\begin{array}{l}\text { Sheep milk } \\
\text { Sheep milk }\end{array}$ & $\begin{array}{l}\text { M. Kaveh, Iran } \\
\text { M. Kaveh, Iran }\end{array}$ \\
\hline 99M & Sheep & $\begin{array}{l}\text { G. S. Cottew, } \\
\text { Australia }\end{array}$ & $\begin{array}{l}\text { Tirgaran P8 (55) } \\
\text { Rimeleh P6 (58) }\end{array}$ & $\begin{array}{l}\text { Sheep milk } \\
\text { Sheep milk }\end{array}$ & $\begin{array}{l}\text { M. Kaveh, Iran } \\
\text { M. Kaveh, Iran }\end{array}$ \\
\hline Sapharpoor (13) & Lamb lung & M. Kaveh, Iran & Groon P20 (61) & Sheep milk & M. Kaveh, Iran \\
\hline Institute P 7 (52) & Goat lung & M. Kaveh, Iran & Turkey 99 P3 (62) & Sheep milk & M. Kaveh, Iran \\
\hline Kordan (25) & Sheep lung & M. Kaveh, Iran & Shiraz Yedollahi (1) & Sheep milk & M. Kaveh, Iran \\
\hline Esfahan (8) & Sheep milk & M. Kaveh, Iran & Mashad (2) & Sheep milk & M. Kaveh, Iran \\
\hline Jamali (12) & Sheep milk & M. Kaveh, Iran & Alshatar P20 (56) & Sheep milk & M. Kaveh, Iran \\
\hline Karaj (17) & Sheep & M. Kaveh, Iran & Chali Morghi (16) & Sheep milk & M. Kaveh, Iran \\
\hline Shiraz (18) & Sheep milk & M. Kaveh, Iran & $S-5(64)^{a}$ & Sheep milk & M. Kaveh, Iran \\
\hline Shiraz (19) & Sheep milk & M. Kaveh, Iran & & & \\
\hline
\end{tabular}

${ }^{a}$ Reference (6).

b Antigenically indistinguishable from $M$. mycoides subsp. mycoides.

mycoides strain G 230 and were found to have no antigenic relationship to any of the caprine and ovine Mycoplasma serotypes or to $M$. mycoides subsp. mycoides strain G 230.

Two of the strains studied, Ghali Morghi (16) and S-5 (64), fermented glucose, reduced tetrazolium chloride, grew at $25 \mathrm{C}$, reduced methylene blue, and grew in a medium containing $0.02 \%$ methylene blue. They did not metabolize arginine hydrochloride or form "film and spots" on an agar medium supplemented with $10 \%$ egg yolk emulsion. They did not grow in serum-free medium, but they lysed sheep red blood cells. These reactions resemble those of $M$. mycoides subsp. mycoides. Both of these strains were inhibited by antisera which we prepared against goat Mycoplasma strains Y-goat and OSB42 at a serum titer of 1:1,280. Both showed an antigenic relationship to $M$. mycoides subsp. mycoides strains PG1 and $\mathrm{KH}_{3} \mathrm{~J}$ when tested by the metabolic-inhibition test.

Fifty-nine purified Mycoplasma strains from goats and sheep were identified as belonging to $M$. agalactiae subsp. agalactiae by the metabolic-inhibition test. The serological reactions of the strains were specific and reproducible for each strain. The biochemical reactions of these strains were identical with one exception: growth in medium containing $0.02 \%$ methylene blue varied. This variability is not uncommon, as is true with strains of most caprine and ovine Mycoplasma serotypes and with bovine $M y c o-$ plasma serotypes (2). Thus $M$. agalactiae subsp. agalactiae appears to constitute a biochemically and serologically homogeneous taxon.

The biochemical characteristics of the strains of $M$. agalactiae subsp. agalactiae investigated in 
this study closely resembled those of $M$. bovigenitalium (4). Both of these organisms reduce tetrazolium chloride, form "film and spots," lyse sheep red blood cells, and require cholesterol for growth; neither ferments carbohydrates, metabolizes arginine hydrochloride, nor grows at $25 \mathrm{C}$.

It has been reported (6) that colony appearance, morphology, growth in fluid medium, reaction in glucose broth, and the change on media containing blood enabled three types, A ( $M$. agalactiae), $\mathrm{N}$, and $\mathrm{C}$, to be separated with certainty. The limited array of biochemical characteristics reported in this study should help greatly to differentiate Mycoplasma strains into groups, but not necessarily into species. Serological tests still remain the primary tools for specific identification of mycoplasmas. Several Mycoplasma strains of Turkish types C and $N(7)$ were obtained from G. S. Cottew of Australia. These were identified as $M$. mycoides subsp. capri and $M$. arginini, respectively.

$M$. agalactiae, $M$. arginini, and $M$. mycoides subsp. capri differ considerably in their biochemical reactions. Arginine is metabolized by strains of $M$. arginini but not by those of the other two organisms; tetrazolium chloride is reduced under aerobic conditions by strains of $M$. agalactiae and $M$. mycoides subsp. capri but not by those of $M$. arginini; glucose is fermented by strains of $M$. mycoides subsp. capri but not by those of the other two organisms; "film and spots" are formed by strains of $M$. agalactiae but not by those of the other two organisms.

This study also confirms the report by Hudson et al. (10) that the $H$ goat strain is serologically and biochemically indistinguishable from $M$. agalactiae.

The cooperation of G. S. Cottew, D. G. ff. Edward, A. Foggie, E. A. Freundt, M. Kaveh, and P. Perreau in supplying Mycoplasma cultures is gratefully acknowledged. Mr. Vincent Stopinski's excellent technical assistance is also acknowledged.

\section{REPRINT REQUESTS}

Address reprint requests to: Dr. J. M. Al-Aubaidi, Plum Island Animal Disease Center, Agricultural Research Service, U.S. Department of Agriculture, Greenport, N.Y. 11944.

\section{LITERATURE CITED}

1. Al-Aubaidi, J. M., and J. Fabricant. 1968. Techniques for the isolation of mycoplasma from cattle. Cornell Vet. 58:555-571.

2. Al-Aubaidi, J. M., and J. Fabricant. 1971 , Characterization and classification of bovine mycoplasma. Cornell Vet. 61:490-518.

3. Al-Aubaidi, J. M., and J. Fabricant. 1971. Methods for purification of mixed cultures of mycoplasma. Cornell Vet. 61:559-572.

4. Aluotto, B., R. G. Wittler, C. O. Williams, and J. E. Faber. 1970. Standardized bacteriologic techniques for the characterization of Mycoplasma species. Int. J. Syst. Bacteriol. 20:35-58.

5. Bridré, J., and A. Donatien. 1923. Le Microbe de l'agalaxie contagieuse et sa culture in vitro. C. $R$. Acad. Sci. 177:841-843.

6. Cottew, G. S. 1970. Diseases of sheep and goats caused by mycoplasmas, p. 198-211. In J. T. Sharp (ed.), The role of my coplasmas and $\mathrm{L}$ forms of bacteria in disease. Charles $\mathrm{C}$ Thomas, Springfield, 111.

7. Cottew, G. S., W. A. Watson, F. A. Arisoy, O. Erdag, and L. S. Buckley. 1968. The differentiation of Mycoplasma agalactiae from other mycoplasmas of sheep and goats. J. Comp. Pathol. 78:275-282.

8. Edward, D., G. ff., and E. A. Freundt. 1956. The classification and nomenclature of organisms of the pleuropneumonia group. J. Gen. Microbiol. 14:197-207.

9. Edward, D. G. ff., and E. A. Freundt. 1973. Type strains of species of the order Mycoplasmatales, including designation of neotypes for Mycoplasma mycoides subsp. mycoides, Mycoplasma agalactiae subsp. agalactiae, and Mycoplasma arthritidis. Int. J. Syst. Bacteriol. 23:55-51.

10. Hudson, J. R., G. S. Cottew, and H. E. Adler. 1967. Diseases of goats caused by mycoplasma: a review of the subject with some new findings. Ann. N.Y. Acad. Sci. 143:287-297.

11. Morton, H. E., and R. J. Roberts. 1967. Production of antimycoplasma (PPLO) antibodies in rabbits. Proc. Soc. Exp. Biol. Med. 125:538-543.

12. Pigoury, L. 1938. L'Agalaxie contagieuse de la chévre au Uhan. Bull Soc. Pathol. Exot. 31:194-199.

13. Purcell, R. H., D. Taylor-Robinson, D. C. Wong, and R. M. Chanock. 1966. A color test for the measurement of antibody to the non-acid forming human mycoplasma species. Amer. J. Epidemiol. $84: 51-66$.

14. Turner, A. W. 1959. Pleuropneumonia group of diseases, p. 437480. In A. W. Stableforth and D. A. Galloway (ed.), Infectious diseases of animals, vol. 2. Butterworth, London.

15. Watson, W. A., G. S. Cottew, O. Erdag, and F. Arisoy. 1968. The pathogenicity of mycoplasma organisms isolated from sheep and goats in Turkey. J. Comp. Pathol. 78:283-291.

16. Zavagli, V. L'agalaxie contagieuse des brebis et des chévres. 1951. Bull. Office Int. Epizoot. 36:336-362. 